\title{
Efficiency of high-carbohydrate fodder in the diets of Holstein cows
}

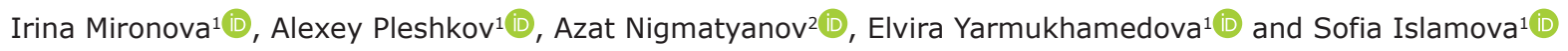 \\ 1. Federal State Budgetary Educational Establishment of Higher Education "Bashkir State Agrarian University", Ufa, \\ Russia; 2. Federal State Budgetary Educational Institution of Higher Education Ufa State Petroleum Technological \\ University (USPTU), Ufa, Russia. \\ Corresponding author: Irina Mironova, e-mail: irina5mironova@rambler.ru \\ Co-authors: AP: alexpleshkov@rambler.ru, AN: axnigmatyanov@rambler.ru, EY: elvyarmukhamedova@rambler.ru, \\ SI: sofislamova@rambler.ru
}

Received: 20-11-2020, Accepted: 05-04-2021, Published online: 25-05-2021

doi: www.doi.org/10.14202/vetworld.2021.1303-1310 How to cite this article: Mironova I, Pleshkov A, Nigmatyanov A, Yarmukhamedova E, Islamova S (2021) Efficiency of high-carbohydrate fodder in the diets of Holstein cows, Veterinary World, 14(5): 1303-1310.

\begin{abstract}
Aim: This study aimed to analyze the efficiency of carbohydrate-enriched rations fed to pasture and stall-housed cows.

Materials and Methods: Forty Holstein cows were divided into four groups of 10 animals each. The experiment lasted 305 days. All animals were kept under the same conditions, except for the amount of energy-carbohydrate rations fed. The control cows were on a standard diet. Experimental groups 1, 2, and 3 received a ration enriched with energy-carbohydrate components at 250,500, and $700 \mathrm{~g} / \mathrm{head} /$ day, respectively. Feed intake was measured on 2 consecutive days each month. During the balance trial, when young animals reached 13 months, feed intake was examined daily. Fodder, its residues, feces, and urine collected during the balance trial were used to determine nutrient digestibility and nitrogen exchange.

Results: Nitrogen balance was positive in all experimental animals. Cows in Group 3 made better use of the digested nitrogen. A biochemical blood test showed higher total protein content in the serum of the experimental cows than in the control by $1.47-3.49 \%(p \leq 0.05-0.001)$ in winter and $0.24-0.98 \%(p \leq 0.01)$ in summer. In winter, the serum protein level increased due to changed feeding routines and shorter exercise times, but did not exceed physiological requirements. The alpha- and gamma-globulins levels increased to $0.2-0.5 \mathrm{~g} / \mathrm{L}$ in winter and $0.3-0.6 \mathrm{~g} / \mathrm{L}$ in summer, and $0.5-1.4 \mathrm{~g} / \mathrm{L}$ in winter and $0.1-0.2 \mathrm{~g} / \mathrm{L}$ in summer, respectively. Beta-globulins decreased. The supplement had a positive effect on milk output, which increased by $67.1-137.3 \mathrm{~kg}(1.93-3.95 \% ; \mathrm{p} \leq 0.05-0.001)$ in the first 100 lactation days, then by $198.2-458.8 \mathrm{~kg}(2.39-$ $5.53 \% ; \mathrm{p} \leq 0.05-0.001)$ for the remaining days. All animals had a high milk yield coefficient, with the experimental groups having $0.64-2.64 \%$ more milk yield than the control. The lactation curves showed that the average daily milk yield of all experimental cows increased, then gradually decreased along the physiological trajectory from the $3^{\text {rd }}$ month until the end of lactation. Milk quality analysis in the experimental groups indicated an increase in the dry matter content by $0.17-$ $0.27 \%(\mathrm{p} \leq 0.001)$ in summer and $0.16-0.27 \%(\mathrm{p} \leq 0.001)$ in winter; higher protein levels by $0.04-0.06 \%$ in summer and $0.03-$ $0.07 \%(\mathrm{p} \leq 0.05)$ in winter; increased fat by $0.09-0.14 \%(\mathrm{p} \leq 0.05-0.001)$ in summer and $0.09-0.13 \%(\mathrm{p} \leq 0.05-0.001)$ in winter; increased density by $0.47-0.61^{\circ} \mathrm{A}(\mathrm{p} \leq 0.05)$ in summer and $0.17-0.27^{\circ} \mathrm{A}$ in winter; and increased energy by $1.70-2.63 \%$ $(\mathrm{p} \leq 0.001)$ in summer and $1.57-2.54 \%(\mathrm{p} \leq 0.01-0.001)$ in winter.
\end{abstract}

Conclusion: The energy-carbohydrate feed "Tanrem" can provide the required energy intake of Holstein cows. The maximum biological and economic effect wads attained at $500 \mathrm{~g}$ per animal.

Keywords: animal breeding, cows, diet, ration cuts.

\section{Introduction}

Holstein cattle account for $67 \%$ of the total cattle population in the Russian Federation. These are large, highly productive animals capable of producing large quantities of milk. The intensive growth and development of young Holstein cattle make the breed particularly interesting for milk production. Although some improvements in the milk yield have been achieved, further rise can be attained by improving the breed's typically low feed conservation ratios[1-4]. One

Copyright: Mironova, et al. Open Access. This article is distributed under the terms of the Creative Commons Attribution 4.0 International License (http://creativecommons.org/licenses/ by/4.0/), which permits unrestricted use, distribution, and reproduction in any medium, provided you give appropriate credit to the original author(s) and the source, provide a link to the Creative Commons license, and indicate if changes were made. creativecommons.org/publicdomain/zero/1.0/) applies to the data made available in this article, unless otherwise stated. The Creative Commons Public Domain Dedication waiver (http://

of the valuable breed qualities of Holstein cattle is the intensive growth and development of juveniles. Improvements in breed-specific traits could increase the breed's genetic potential for milk productivity and improve the breed's suitability for industrial maintenance, since the husbandry requirements for Holstein cattle are very high. If these needs are not met (i.e., only the physiological needs are fulfilled), then the breed suffers from low feed conversion ratios and their genetic potential is not attained [5].

Previous research has shown that food additive enriched diets increase livestock productivity. Such diets must be formulated to meet the animal's nutritional needs, while also considering the feed's safety, cost, and preferably waste-free production $[6,7]$. The diet formulation requires a thorough selection of fodders to transform the necessary amount of nutrients and energy into the animal's body [8-10]. During 
lactation, dairy cattle must consume enough energy and nutrients, since the body's glucose requirements during this period are 3 times higher than average due to milk production $[11,12]$. Farmers often address this problem by increasing the proportion of concentrates, oilseed residues, cakes, and grain fodder; however, these feeds also increase the blood's protein content, resulting in health problems, such as ketosis, acidosis, and reproductive disorders [13].

In recent years, scientists and practitioners have become interested in energy supplements as a means to prevent balance problems, weight reduction, metabolic abnormalities, and reproductive disorders $[4,14,15]$. A wide assortment of energy supplements in a variety of formulations is currently available for livestock. The most widely used additive is propylene glycol. With a daily dosage of $100-$ $300 \mathrm{~g}$ per animal, it improves the digestibility of dry and organic matter, and increases milk yields. When given with glycerin and niacin, these improvements are increased further. The same effect can be achieved using protected fat (300 g/animal/day), hepatoprotectors in the form of protected B vitamins [16-18].

When increasing milk output, it is important to assess the cow's protein metabolism, since it is involved in all body functions. Digestive enzymes break down feed protein into polypeptides and amino acids, which are then absorbed into the blood. Nitrogen, a building block of organic matter, can be used to evaluate the feed intake amounts. Nitrogen balance can be positive, negative, or zero and can be used to estimate the digested protein weight, as well as the potential increase or decrease in the animal's protein [19]. Vital body functions depend on biochemical processes that affect product synthesis. Changes in blood composition indicate metabolism intensity and the associated processes of growth, development, and productivity. Thus, biochemical blood tests were used to analyze feed efficiency and potential productivity [20].

Animals with similar heredity develop differently under the influence of varied environmental conditions [2,21]. This study aimed to analyze the efficiency of carbohydrate-enriched rations fed to pasture and stall-housed cows.

\section{Materials and Methods}

\section{Ethical approval}

The animals were treated in accordance with the instructions and guidelines of Russian Regulations, 1987 (Order No. 755 on 12.08.1977 the USSR Ministry of Health) and "The Guide for Care and Use of Laboratory Animals" (National Academy Press Washington, D.C. 1996)" The number of testing samples was minimal.

\section{Study period and location}

The study was conducted during 2019 and 2020 in Agroalliance LLC, located in the Chishmy district of the Bashkortostan Republic.

\section{Research target}

The experiment was carried out in the South Ural climate and lasted for 305 lactation days. A total of 40 Holstein cows were used in the research. The cows were selected by analogy from the cattle raised on the farm. The animals were kept at pasture for 6 months from the start of the experiment. As the weather worsened, the cattle were kept indoors. All animals were kept in the same conditions and the cows were allocated into four groups: A control group and three experimental groups. The control group received a standard diet, while the experimental animals in Groups 1,2, and 3 were fed diets enriched with carbohydrates at a daily dose of 250, 500, and $700 \mathrm{~g} / \mathrm{animal} /$ day, respectively. The feed supplement differed from other additives in that it had easy hydrolysable carbohydrates and zero non-protein, nitrogenous compounds.

The cow diets were formulated differently for indoor versus pasture use and were analyzed independent of the four groups. At pasture, the cow diets consisted of $80.4-86.9 \%$ succulent fodder and $12.2-13.1 \%$ concentrates. During indoor maintenance, the cows were fed $24.3-25.9 \%$ succulent feed, $34.4-36.7 \%$ concentrates, and $35.0-37.4 \%$ roughages. The succulent fodder share decreased with addition of the tested additive. The pasture ration for all groups consisted of grass, legumes, barley, oats, peas, table salt, and monosodium phosphate. During the stall feeding period, the grass was replaced with alfalfa haylage, barley straw, corn silage, molasses, and a pre-mixed P60-1 additive. Juvenile animals in the groups were fed diets enriched with the "Tanrem" additive at a dose of $0.25 ; 0.50$; and $0.75 \mathrm{~g}$ for Groups 1-3, respectively. The rations were formulated based on milk productivity level, the physiological state of the cows, and feed quality and were occasionally adjusted. The diet was balanced in a program designed to calculate nutritional needs to plan the appropriate preparation and consumption of the feed during different cattle maintenance periods.

\section{Preparation}

Treatments were based on a new, high-carbohydrate energy additive that was introduced in different dosages in the feed mixture and fed in twice daily: In the morning and at 2-3 o'clock in the afternoon. The distinctive feature of the feed additive Tandem (Kapital-Prok; Moscow region, Balashikha) is its low protein content and high level of extended-release energy, which is essential for cows after calving to increase milk production and weight gain. The supplement developers recommend using this additive instead of molasses, protected fats, and propylene glycol. The additive contains at least $50 \%$ easily digestible carbohydrates, including up to $27 \%$ sucrose, $8.0 \%$ vegetable protein, and $12 \%$ fat. The studied feed is a fine powder of uniform consistency and is light yellow to dark brown in color. The supplement consists of fibers aimed at activating rumen motility. The developers made it more palatable with a chocolate taste 
and flavor for better intake and absorption. The ingredients include natural prebiotics and energy additives, which activate metabolic processes.

\section{Diagnostic methods}

The biochemical blood parameters were measured using conventional methods. The blood samples were taken from the jugular vein of healthy cows in the morning before feeding and watering. Specifically, biosubstrates were collected into vacuum tubes with a coagulation activator (thrombin). Biochemical analysis was performed with an automatic analyzer CS-T240 (Dirui Industrial Co., Ltd., China) using the commercial veterinary kits, DiAvTest (Russia) and Randox Laboratories Limited (UK).

The digestion trial involved preparatory (3 days), preliminary (15 days), and accounting (10 days) periods. Three representative animals from each group were selected. During the preliminary period, the remnants from previous feed were removed from the gastrointestinal tract of the experimental animals, then were filled with the tested feed additive. During the accounting period, the amount of feed consumed (including residues) and the amount of feces excreted were recorded. Then, the fodder and feces were analyzed for moisture, dry matter, protein, fat, fiber, nitrogen-free extractive substances, and minerals. Digested substances were calculated as the difference between their average daily intake and their average excretion in feces.

The difference between the amount of nitrogen ingested and the amount of nitrogen excreted from the body is called the nitrogen balance. Nitrogen balance measurement involves the analyses of the digestibility of nitrogenous substances in the diet and nitrogen exchange. In other words, a common digestion trial is supplemented by urine collection and nitrogen content calculation. The total nitrogen excretion per day is measured based on the quantitative and chemical analysis of the excreted feces and urine. When conducting experiments with lactating cows, the nitrogen content in the daily milk yield is also considered. Nitrogen balance can be used to determine the amount of protein accumulated or broken down (in negative nitrogen balance). Nitrogen balance was calculated based on the balance experiment data. During this period, the weight of the specified feed and their residues was measured, as was urine, feces, and milk output. All samples for laboratory testing were preserved. Feces from animals were collected in enameled tanks, then filled with $10 \%$ hydrochloric acid at the rate of $50 \mathrm{ml}$ per $1 \mathrm{~kg}$ of feces and add $2 \mathrm{ml}$ of chloroform. The storage box with feces was kept in the cold. Every day, the feces were weighed, mixed well, taken 1-2 \% by weight of feces from different places and placed in jars with ground stoppers. Fecal samples were preserved by adding $100 \mathrm{ml}$ of $10 \%$ hydrochloric acid solution and $2 \mathrm{ml}$ of chloroform per $1 \mathrm{~kg}$ of feces. The samples were stored in a cool place before analysis. Urine, as excreted by animals, was collected in a prepared bottle with pre-poured $10-15 \mathrm{~cm}^{3}$ of a $10 \%$ hydrochloric acid solution and 2-3 g of thymol. Ten percentage of average urine samples were taken from the daily urine excretion and placed in bottles with ground stoppers. The samples were additionally preserved with a $10 \%$ solution of hydrochloric acid, so that the total amount of added acid was $5 \%$ of the sample weight. Then 2-3 $g$ of thymol was added once or twice during the experiment. The samples were stored at a temperature of $3-5^{\circ} \mathrm{C}$ until the end of the analysis. In lactating animals, milk was recorded and average samples were taken for analysis at each milking. The milk samples were approximately $1-2 \%$ of the milk yield. The minimum daily sample size was $100 \mathrm{ml}$. The milk was preserved with formalin ( 8 drops per 1 liter of milk). The nitrogen balance was determined by the formula:

Feed nitrogen $=$ Feces nitrogen+Urine nitrogen+Nitrogen retention.

Milk productivity was evaluated for 305 days of lactation according to monthly control milking. Test milking is used to evaluate daily milk productivity, fat, and protein percentages. Lactation curves for the control and experimental groups were constructed. Milk production per month was calculated by the daily milk yield multiplied by 30 . The milk yield coefficient was calculated based on the milk output for 305 days, the cows' live weight, the stability index, and the lactation efficiency [22]. The lactation efficiency was calculated by the formula: $\mathrm{LE}=(\mathrm{TMY} /[\mathrm{HDY} \times \mathrm{n}]) \cdot 100$, where LE is the lactation efficiency; TMY is the total milk yield for lactation; HDY is the highest daily yield; and $\mathrm{n}$ is the lactation length. The lactation stability index was determined by: LSI $=($ MY2/MY1)*100, where MY1 is the milk yield for the first 90 days of lactation; and MY2 is the milk yield for the second 90 days of lactation.

\section{Statistical analysis}

Standard animal examination methods for the biometric processing of test samples were used supported with Microsoft Excel-2010 software (Microsoft, USA). The difference in mean indicators was considered reliable per the Student's criterion (at $\mathrm{p}<0.05 ; \mathrm{p}<0.01$; and $\mathrm{p}<0.001)$. We focused on the feeding factor to determine its effect on productivity, thus, the normal distribution was not checked before the $t$-test.

\section{Results}

The average daily nitrogen balance was positive in all experimental animals (Figure-1). The nitrogen intake in the experimental groups was increased by 8.9-23.0 g (2.5-6.4\%; $\mathrm{p} \leq 0.05-0.01)$. The highest level of excreted nitrogen in the feces was in the control group, with values $0.4-2.0 \mathrm{~g}(0.3-1.7 \%)$ more than in the experimental groups. Most of all, total nitrogen was released with feces, urine, and milk in the control group, which exceeded the experimental animals by 


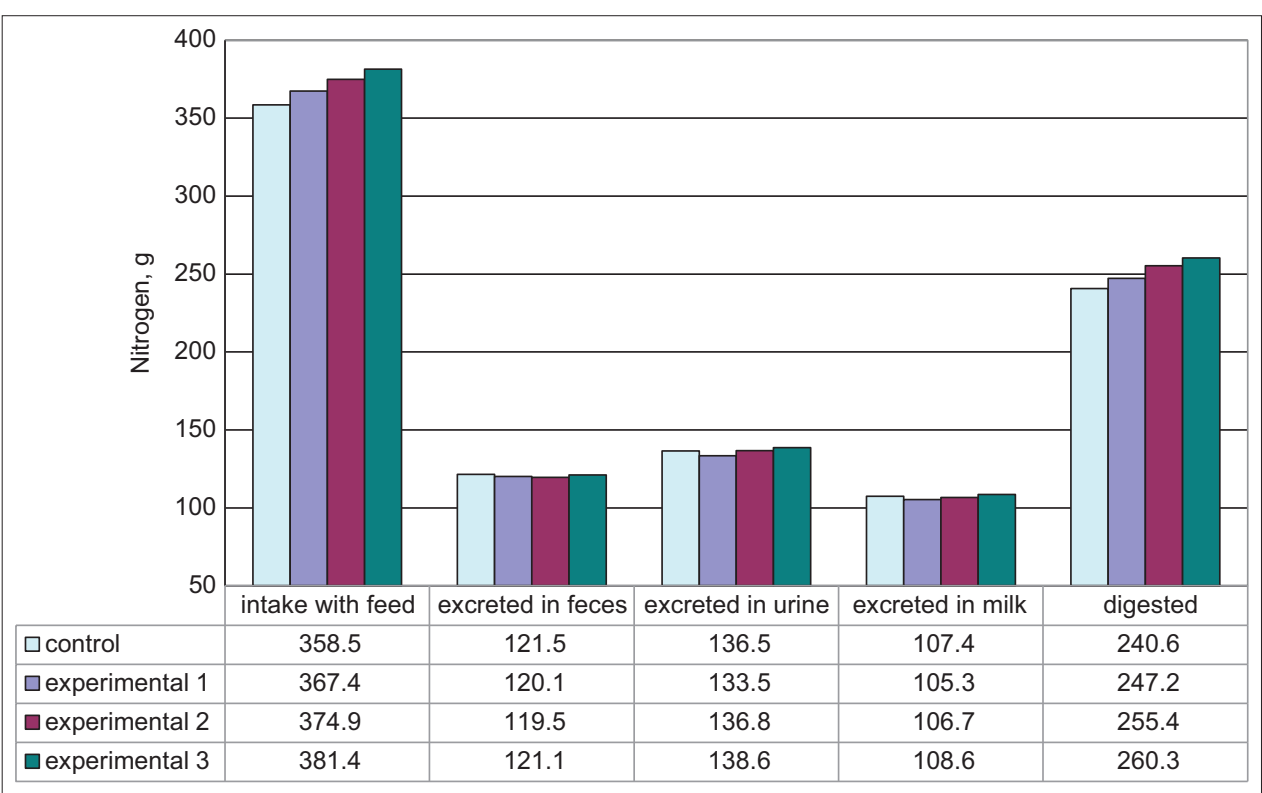

Figure-1: Nitrogen balance in cows, $n=3$.

4.6-13.8 (1.3-3.9\%) with an unreliable difference. The nitrogen utilization in the control group was $30.2 \%$ of their total nitrogen intake, which is $0.8-1.7 \%$ lower than in the experimental groups. In addition, the nitrogen utilization from the digested was $38.1 \%$ in the control animals, which is lower than in the experimental cows by $0.5-1.7 \%$. The control animals used more nitrogen for milk production $(29.1 \%)$ than they consumed, which was $0.4-0.6 \%$ higher than the experimental groups. The control group used $43.3 \%$ of their digested nitrogen, which was $0.7-1.6 \%$ more than the experimental groups.

The high-carbohydrate energy supplement had a positive effect on the biochemical homeostasis of the experimental animals (Table-1). Thus, relative to the control animals, the experimental Holstein cows had an increased total protein content by 1.1-2.6 g/L $(1.47-3.49 \% ; \mathrm{p} \leq 0.05-0.001)$ in winter and $0.2-0.8 \mathrm{~g} / \mathrm{L}$ $(0.240 .98 \% ; \mathrm{p} \leq 0.01)$ in summer. The albumin and globulin content in all seasons had similar results to the total protein levels. In winter, the concentration of serum albumin in the control cows was $36.0 \mathrm{~g} / \mathrm{L}$, which was higher by $1.7-3.6 \%$ and $0.49-1.23 \%$ than the experimental groups. The reliability of these results was confirmed by the second and third experimental groups in all seasons of the year. The blood serum globulin fractions consisted of alpha-, beta-, and gamma-globulins. The alpha- and gamma-globulin levels in the blood of the experimental groups tended to be higher. Alpha-globulins were more by $0.2-0.5 \mathrm{~g} / 1$ in winter and by 0.3-0.6 g/1 in summer, while gamma-globulins were more by $0.5-1.4 \mathrm{~g} / 1$ and $0.1-0.2 \mathrm{~g} / 1$, respectively. The beta-globulin levels in the control group compared to the experimental ones was higher both in winter and summer

The new energy supplement increased cattle milk productivity in the first 100 days of lactation (Table-2). The experimental cows exceeded the control cows in terms of milk output. For the first 100 days of lactation, the milk yields in the experimental cows were increased by $67.1 \mathrm{~kg}(1.93 \% ; \mathrm{p} \leq 0.05)$ in Group 1 ; by $137.3 \mathrm{~kg}(3.95 \% ; \mathrm{p} \leq 0.001)$ in Group 2 ; and by $123.8 \mathrm{~kg}(3.56 \% ; \mathrm{p} \leq 0.001)$ in Group 3. For the entire 305 days period, milk yield was higher by $198.2 \mathrm{~kg}$ $(2.39 \% ; \mathrm{p} \leq 0.05)$ for Group 1; $458.8 \mathrm{~kg}(5.53 \%$; $\mathrm{p} \leq 0.001)$ for Group 2; and $408.9 \mathrm{~kg}(4.93 \% ; \mathrm{p} \leq 0.001)$ for Group 3.

One of the most significant indicators for the assessment of milk productivity is the milk yield coefficient. Its value indicates the mass of milk produced per $100 \mathrm{~kg}$ live weight of the animal. This coefficient can indirectly demonstrate the metabolic pathways in the animal body, including the productivity traits of the livestock. A high milk yield coefficient was found for all experimental cows, which indicates their pronounced dairy type. Simultaneously, a comparative analysis between the groups showed that the milk yield coefficient in the experimental animals was $10.0-41.5 \mathrm{~kg}(0.64-2.64 \%)$ higher than in the control cows.

Since milk production during the entire lactation period was not even, lactation curves based on the average daily milk yields were constructed (Figure-2). Although the $1^{\text {st }}$ month values were approximately the same in all groups, the average daily milk yield of the control cows was reduced in the $2^{\text {nd }}$ month (34.15$34.20 \mathrm{~kg}$ ). The daily milk yield in the control group was $36.80 \mathrm{~kg}$ by the $2^{\text {nd }}$ month, while the daily milk yields in the experimental groups were $0.97-2.16 \mathrm{~kg}$ $(2.64-5.87 \% ; \mathrm{p} \leq 0.05-0.001)$ more. In the $3^{\text {rd }}$ and subsequent lactation months, there was a gradual decrease in the average daily milk yield of all groups. One of the main indicators of lactation evenness is the lactation stability index and the lactation efficiency indicator, which give a more detailed assessment of lactation curves (Figure-3). 
Table-1: Protein composition of blood serum, $g / L(X \pm S x)$.

\begin{tabular}{|c|c|c|c|c|c|}
\hline \multirow[t]{2}{*}{ Indicator } & \multirow[t]{2}{*}{ Season } & \multicolumn{4}{|c|}{ Group } \\
\hline & & Control & Experimental 1 & Experimental 2 & Experimental 3 \\
\hline \multirow[t]{2}{*}{ Total protein } & Winter & $74.6 \pm 0.24$ & $75.7 \pm 0.30 *$ & $77.2 \pm 0.23 * * *$ & $77.1 \pm 0.57 * *$ \\
\hline & Summer & $81.9 \pm 0.16$ & $82.1 \pm 0.12$ & $82.7 \pm 0.19 * *$ & $82.7 \pm 0.18 * *$ \\
\hline \multirow[t]{2}{*}{ Albumins } & Winter & $36.0 \pm 0.30$ & $36.6 \pm 0.34$ & $37.3 \pm 0.40 *$ & $37.3 \pm 0.40 *$ \\
\hline & Summer & $40.5 \pm 0.06$ & $40.7 \pm 0.08$ & $41.0 \pm 0.14^{*}$ & $41.0 \pm 0.16 *$ \\
\hline \multirow[t]{2}{*}{ Globulins } & Winter & $38.6 \pm 0.49$ & $39.1 \pm 0.51$ & $39.9 \pm 0.17 *$ & $39.9 \pm 0.94$ \\
\hline & Summer & $41.4 \pm 0.11$ & $41.4 \pm 0.17$ & $41.7 \pm 0.12$ & $41.7 \pm 0.28$ \\
\hline \multirow[t]{2}{*}{ Alpha } & Winter & $10.5 \pm 0.26$ & $10.7 \pm 0.31$ & $11.0 \pm 0.05$ & $10.9 \pm 0.08$ \\
\hline & Summer & $10.0 \pm 0.27$ & $10.3 \pm 0.33$ & $10.6 \pm 0.30$ & $10.5 \pm 0.40$ \\
\hline \multirow[t]{2}{*}{ Beta } & Winter & $11.5 \pm 0.29$ & $11.2 \pm 0.21$ & $10.8 \pm 0.18$ & $11.0 \pm 0.26$ \\
\hline & Summer & $11.1 \pm 0.07$ & $10.8 \pm 0.14 *$ & $10.7 \pm 0.28$ & $10.8 \pm 0.34$ \\
\hline \multirow[t]{2}{*}{ Gamma } & Winter & $16.7 \pm 0.84$ & $17.2 \pm 0.76$ & $18.1 \pm 0.28$ & $17.9 \pm 0.70$ \\
\hline & Summer & $20.3 \pm 0.43$ & $20.4 \pm 0.61$ & $20.4 \pm 0.46$ & $20.5 \pm 0.84$ \\
\hline \multirow[t]{2}{*}{ Albumin-globulin coefficient } & Winter & $0.93 \pm 0.02$ & $0.93 \pm 0.02$ & $0.94 \pm 0.01$ & $0.94 \pm 0.03$ \\
\hline & Summer & $0.98 \pm 0.01$ & $0.98 \pm 0.01$ & $0.98 \pm 0.01$ & $0.98 \pm 0.01$ \\
\hline
\end{tabular}

Table-2: Milk production.

\begin{tabular}{lcccc}
\hline \multirow{2}{*}{ Indicator } & \multicolumn{3}{c}{ Group } \\
\cline { 2 - 5 } & Control & Experimental 1 & Experimental 2 & Experimental 3 \\
\hline Milk yield for 305 days in milk, $\mathrm{kg}$ & $8292.4 \pm 69.93$ & $8490.6 \pm 67.73^{*}$ & $8751.2 \pm 42.24 * * *$ & $8701.3 \pm 46.06 * * *$ \\
Milk yield for 100 days in milk, $\mathrm{kg}$ & $3473.0 \pm 18.75$ & $3540.1 \pm 22.15^{*}$ & $3610.3 \pm 17.38 * * *$ & $3596.8 \pm 18.79 * * *$ \\
Average daily milk yield, $\mathrm{kg}$ & $27.2 \pm 0.23$ & $27.8 \pm 0.22^{*}$ & $28.7 \pm 0.14^{* * *}$ & $28.5 \pm 0.15^{* * *}$ \\
Milk yield coefficient, $\mathrm{kg}$ & $1572.0 \pm 12.29$ & $1582.0 \pm 14.30$ & $1613.5 \pm 10.71^{*}$ & $1613.5 \pm 10.88^{*}$ \\
\hline
\end{tabular}

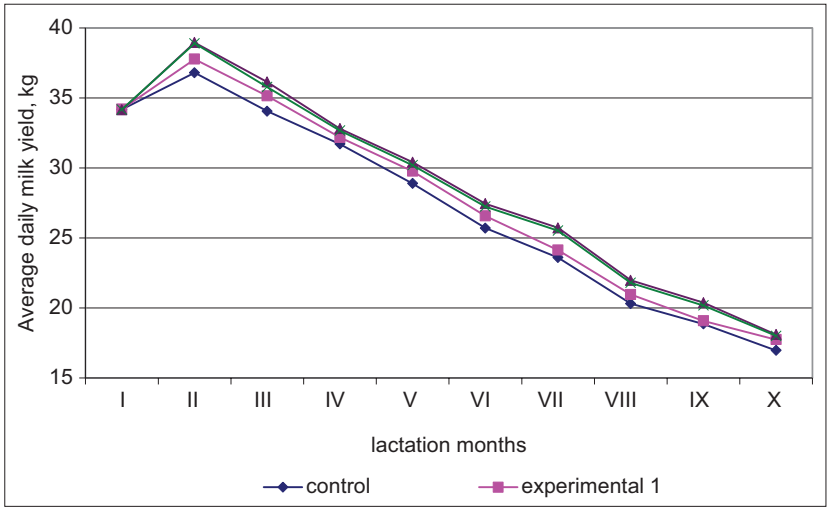

Figure-2: Lactation curves by lactation months.

All the animals involved in the experiment had stable milk yields throughout lactation. The milk yields were increased by $0.4 \%$ in Group 1 , by $0.8 \%$ in Group 2, and by $0.6 \%$ in Group 3. The lactation efficiency ratio was increased by $0.1 \%$ in Group $1,0.3 \%$ in Group 2, and $0.2 \%$ in Group 3.

Another essential production efficiency indicator is the quality of raw milk. The higher the milk quality, the higher the level of valuable ingredients, which reduces production costs, provides additional returns, and increases profitability. The energy supplement "Tanrem" affected milk quality (Table-3). The dry matter content in the control cows' milk was lower than the experimental groups by $0.17-0.27 \%$ $(\mathrm{p} \leq 0.001)$ in summer and by $0.16-0.27 \%(\mathrm{p} \leq 0.001)$ in winter. The level of non-fat milk solids was lower by $0.08-0.12 \%(\mathrm{p} \leq 0.05)$ and $0.06-0.14 \%(\mathrm{p} \leq 0.01)$, respectively.
The quality of milk obtained from the experimental cows in terms of fat and protein content exceeded similar indicators in samples collected from the control cows. Specifically, the protein content increased by $0.04-0.06 \%$ in summer milk and by $0.03-$ $0.07 \%(\mathrm{p} \leq 0.05)$ in winter milk. In addition, fat was increased by $0.09-0.14 \%(\mathrm{p} \leq 0.05-0.001)$ and 0.09 $0.13 \%$ ( $\leq \leq 0.05-0.001)$ due to the need for sufficient energy intake and activated metabolic processes in the animals' bodies.

\section{Discussion}

Manufacturers recommend the use of energy and carbohydrate additives in the diet of cows after calving and during early lactation. In this regard, the new high-carbohydrate energy supplement Tanrem was introduced into the diet of cows at a dose of 250$700 \mathrm{~g} /$ animal/day. Automated ration formulations were performed per Ventsova and Safonov, Torzhkov et al. $[23,24]$. The pasture diet was mainly comprised succulent fodder, while the indoo' $r$ feeding consisted of roughages and concentrates. During the entire observation period, the proportion of succulent feed decreased with the introduced supplement. Animals receiving the high-carbohydrate energy additive were better able to digest nitrogen in their feed than the cows fed the control diet, with a statistical difference $(\mathrm{p}<0.05)$ in the daily nitrogen balance of 6.6-19.6 $\mathrm{g}$ (2.7-8.2\%). The cows consuming the studied supplement at a dose of $700 \mathrm{~g} /$ day/animal had the highest nitrogen utilization efficiency. Group 2 had moderately lower results. Mironova et al. [12] revealed that the energy supplement had the best effect on the 
Table-3: Chemical composition and quality of milk.

\begin{tabular}{|c|c|c|c|c|c|}
\hline \multirow[t]{2}{*}{ Indicator } & \multirow[t]{2}{*}{ Season of the year } & \multicolumn{4}{|c|}{ Group } \\
\hline & & Control & Experiment 1 & Experiment 2 & Experiment3 \\
\hline \multirow[t]{2}{*}{ Acidity, oT } & Summer & $16.69 \pm 0.07$ & $16.72 \pm 0.04$ & $16.74 \pm 0.02 *$ & $16.74 \pm 0.04 *$ \\
\hline & Winter & $16.90 \pm 0.05$ & $17.01 \pm 0.06$ & $17.06 \pm 0.05$ & $17.06 \pm 0.06$ \\
\hline \multirow[t]{2}{*}{ Density, oA } & Summer & $26.97 \pm 0.18$ & $27.44 \pm 0.14 *$ & $27.58 \pm 0.16^{*}$ & $27.54 \pm 0.14^{*}$ \\
\hline & Winter & $28.69 \pm 0.06$ & $28.86 \pm 0.01$ & $28.96 \pm 0.16$ & $28.90 \pm 0.17$ \\
\hline \multirow[t]{2}{*}{ Moisture, \% } & Summer & $87.89 \pm 0.01$ & $87.72 \pm 0.03 * * *$ & $87.62 \pm 0.06 * * *$ & $87.65 \pm 0.04 * * *$ \\
\hline & Winter & $87.60 \pm 0.20$ & $87.44 \pm 0.02 * * *$ & $87.33 \pm 0.02 * * *$ & $87.35 \pm 0.05^{* * *}$ \\
\hline \multirow[t]{2}{*}{ Dry matter, \% } & Summer & $12.11 \pm 0.01$ & $12.28 \pm 0.03 * * *$ & $12.38 \pm 0.06 * * *$ & $12.35 \pm 0.04 * * *$ \\
\hline & Winter & $12.40 \pm 0.02$ & $12.56 \pm 0.02 * * *$ & $12.67 \pm 0.02 * * *$ & $12.65 \pm 0.05^{* * *}$ \\
\hline \multirow[t]{2}{*}{ SOMO, \% } & Summer & $8.44 \pm 0.03$ & $8.52 \pm 0.01 *$ & $8.56 \pm 0.04 *$ & $8.55 \pm 0.03 *$ \\
\hline & Winter & $8.63 \pm 0.03$ & $8.69 \pm 0.03$ & $8.77 \pm 0.02 * *$ & $8.75 \pm 0.01^{* *}$ \\
\hline \multirow[t]{2}{*}{ Mass fraction of fat, $\%$} & Summer & $3.67 \pm 0.02$ & $3.76 \pm 0.02 *$ & $3.81 \pm 0.02 * * *$ & $3.80 \pm 0.02 * *$ \\
\hline & Winter & $3.77 \pm 0.03$ & $3.86 \pm 0.04 *$ & $3.90 \pm 0.01 * * *$ & $3.90 \pm 0.04 *$ \\
\hline \multirow[t]{2}{*}{ Mass fraction of protein, $\%$} & Summer & $3.13 \pm 0.03$ & $3.17 \pm 0.02$ & $3.19 \pm 0.03$ & $3.18 \pm 0.02$ \\
\hline & Winter & $3.25 \pm 0.03$ & $3.28 \pm 0.3$ & $3.32 \pm 0.01 *$ & $3.31 \pm 0.02$ \\
\hline \multirow[t]{2}{*}{ Lactose, \% } & Summer & $4.63 \pm 0.01$ & $4.65 \pm 0.01$ & $4.66 \pm 0.01 *$ & $4.66 \pm 0.01 *$ \\
\hline & Winter & $4.68 \pm 0.02$ & $4.70 \pm 0.02$ & $4.73 \pm 0.02 *$ & $4.72 \pm 0.01 *$ \\
\hline \multirow[t]{2}{*}{ Ash, \% } & Summer & $0.69 \pm 0.01$ & $0.70 \pm 0.01$ & $0.71 \pm 0.01 *$ & $0.71 \pm 0.01$ \\
\hline & Winter & $0.70 \pm 0.01$ & $0.71 \pm 0.01$ & $0.72 \pm 0.01$ & $0.71 \pm 0.01$ \\
\hline \multirow[t]{2}{*}{ Calorie content, kcal } & Summer & $70.99 \pm 0.08$ & $72.20 \pm 0.27 * * *$ & $72.86 \pm 0.41 * * *$ & $72.65 \pm 0.26 * * *$ \\
\hline & Winter & $72.86 \pm 0.13$ & $74.01 \pm 0.21 * * *$ & $74.71 \pm 0.10 * * *$ & $74.59 \pm 0.43^{* *}$ \\
\hline
\end{tabular}

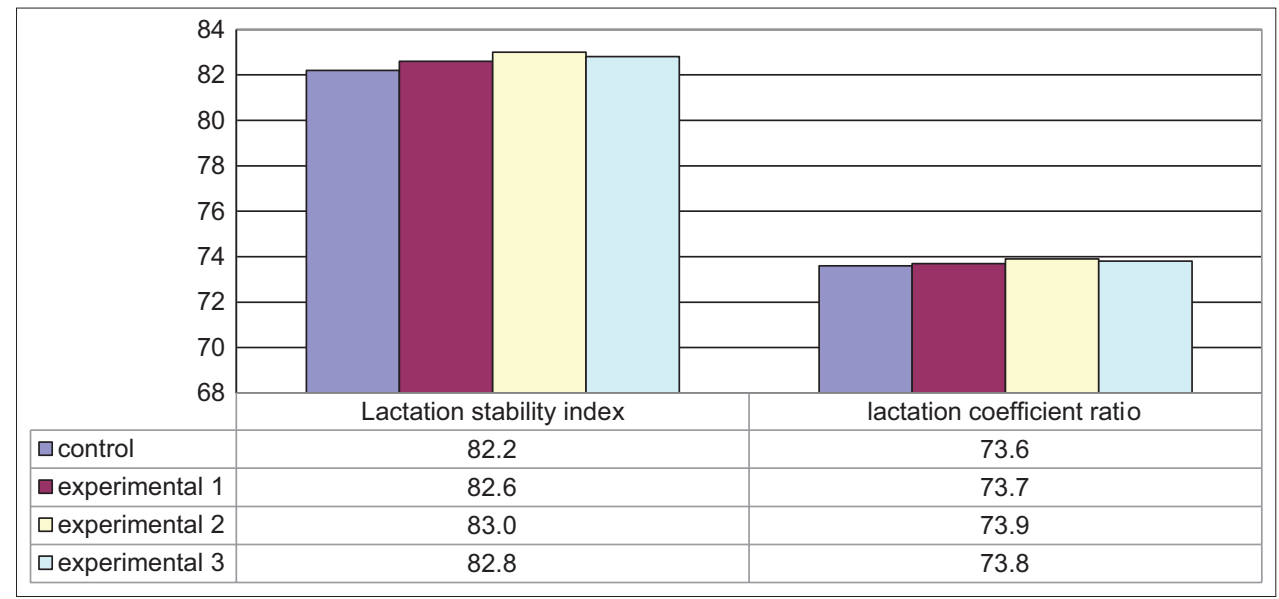

Figure-3: Lactation coefficients.

nutrient and energy digestibility in the experimental cows.

The total protein level in the blood serum varied from 74.6-77.2 $\mathrm{g} / \mathrm{L}$ in summer to $81.9-82.7 \mathrm{~g} / \mathrm{L}$ in winter due to changes in feeding systems, nutrient composition in the feed, and reduced exercise in the winter. The biochemical composition of the blood serum was improved in the experimental cows, due to their higher dry mater absorption abilities, which also resulted in the higher total protein content of the experimental groups. The experimental animals had increased serum albumin levels and higher amounts of alpha- and gamma- globulins in winter, with beta-globulin content being the lowest. Changes in the quantitative composition of protein fractions make it possible to understand ongoing immune processes. The use of a new feed did not have a negative effect on animal immunity, which is consistent with the results of Andreeva et al. [10,13]. There was evident activation of biological protein synthesis and improved body defenses in response to changing weather conditions in the experimental groups. All data obtained were within physiological standards.

Milk yield is the most critical indicator of lactating cows. Lactation involves intense physiological and biochemical metabolic processes in the body due to the conversion of a large amount of energy and feed nutrients into milk. Additional energy sources are critical in the first 100 days of lactation in cows. Extra energy provides for milk synthesis without consuming the accumulated nutrient reserves in the body and the use of supplements does not decrease productivity. The second experimental group of cows (500 g supplement) had the highest milk productivity. The milk yield coefficient analysis revealed high milk productivity in all the studied groups, indicating the cows' pronounced dairy type. A similar pattern was established by Safonov [11] and Mironova et al. [12].

Milk quality can also be evaluated by its density, which was higher in the experimental cows by 
$0.47-0.61^{\circ} \mathrm{A}(\mathrm{p} \leq 0.05)$ in summer and by $0.17-0.27^{\circ} \mathrm{A}$ in winter. Similar seasonal dynamics was found in studies of new biologically active substances conducted by Gorlov et al. [25]. When comparing milk acidity values, there was a more pronounced seasonal variability, with increased acidity found in the winter: $0.21^{\circ} \mathrm{T}$ in the control sample, $0.29^{\circ} \mathrm{T}$ in Group 1, and $0.32^{\circ} \mathrm{T}$ in Groups 2 and 3. An intergroup analysis demonstrated higher acidity in the experimental samples by $0.03-0.05^{\circ} \mathrm{T}(\mathrm{p} \leq 0.05)$ in summer and by 0.11 $0.16^{\circ} \mathrm{T}$ in winter due to increased protein content. The milk acidity and density were within the regulatory limits set by the interstate standard for raw milk. Seasonal differences in milk composition and properties were previously studied by Kalaeva et al. [26] and Kakimov et al. [27]. The authors found a slight increase in milk acidity in the autumn-winter period, which can be explained by changes in animal nutrition. Higher nutrient content in the milk of the experimental animals increased its energy value. The caloric content of milk in the experimental samples increased by $1.21-1.87 \mathrm{kcal}(1.70-2.63 \% ; \mathrm{p} \leq 0.001)$ in summer and by $1.15-1.85 \mathrm{kcal}(1.57-2.54 \% ; \mathrm{p} \leq 0.01-0.001)$ in winter. Physicochemical milk characteristics in all the experimental groups varied by season and under the influence of the tested additive. The supplement had a positive effect due to the higher content of fat, protein, and dry matter, which increased the nutritional, biological, and energy values of the feed.

\section{Conclusion}

The enrichment of dairy cattle diets with high-carbohydrate energy additives is very promising. Our tested feed additive improved nitrogen utilization and biochemical blood values, increased milk yields, and had a positive effect on the milk's chemical composition and quality. Compared to the control cows, the experimental Holstein animals had higher total protein content, increased albumins, increased milk yields, higher dry matter concentrations, increased protein content, and higher fat contents. The most positive effect on these parameters was achieved using the Tanrem supplement at a dose of 500-700 g/animal/day. It is important to note that high-quality feed preparation and proper diet formulations provide feed additives for specific physiological periods only. The studied energy supplement will not solve all the problems in dairy farming. Still, it will eliminate the negative energy balance after calving, maintain the health and welfare of the cows, increase milk yields, and bring in additional profit.

\section{Authors' Contributions}

AP: Initiated and developed the study under the guidance of IM. AN: Collected samples. EY: Examined milk chemical composition and quality. SI: Analyzed the data. IM: Drafted the manuscript. SI: Drafted and reviewed the manuscript. All the authors have read and approved the final manuscript.

\section{Acknowledgments}

The authors of the study are grateful to the company "Capital-Prok" for the given opportunity to conduct research and make recommendations on the optimal dosages of the new supplement. We thank Agroalliance LLC for providing the animals for research purposes. The research was conducted within the thematic research plan of the Bashkir State Agrarian University (No. 01201058950) "Development and improvement of livestock products production technologies."

\section{Competing Interests}

The authors declare that they have no competing interests.

\section{Publisher's Note}

Veterinary World remains neutral with regard to jurisdictional claims in published institutional affiliation.

\section{References}

1. Sharipova, A., Khaziev, D., Kanareikina, S., Kanareikin, V., Rebezov, M., Kazanina, M., Andreeva, A., Okuskhanova, E., Yessimbekov, Z. and Bykova, O. (2017) The effects of a probiotic dietary supplementation on the amino acid and mineral composition of broilers meat. Annu. Res. Rev. Biol., 21(6): 1-7.

2. Khabibullin, R., Khabibullin, I., Yagafarov, R., Bakirova, A., Fazlaev, R., Karimov, F., Mussina, L., Ismagilova, E., Fazlaeva, S. and Tuktarov, V. (2019) The influence of dietary supplements on the adaptive processes in animals after physical stress. Bulg. J. Agric. Sci., 25(2): 105-118.

3. Khaziakhmetov, F.S., Khabirov, A.F., Avzalov, R.K., Tsapalova, G.R., Rebezov, M.B., Tagirov, K., Giniyatullin, S.S., Ishmuratov, K.G., Mishukovskaya, G.S., Gafarova, F.M. and Yessimbekov, Z.S. (2018) Effect of probiotics on calves, weaned pigs and lamb growth. Res. $J$. Pharm. Biol. Chem. Sci., 9(3): 866-870.

4. Makarov, P.M., Stepanova, I.A., Nazarova, A.A. and Polishchuk, S.D. (2017) Carbohydrate metabolism and milk productivity of Holstein cows when using cobalt nanopowder in diets. Zootechny, 6(1): 25-28.

5. Sedykh, T.A., Gizatullin, R.S., Kosilov, V.I., Chudov, I.V., Andreeva, A.V., Giniyatullin, M.G., Islamova, S.G., Tagirov, K.K. and Kalashnikova, L.A. (2018) Adapting Australian Hereford cattle to the conditions of the Southern Urals. Res. J. Pharm. Biol. Chem. Sci., 9(3): 885-898.

6. Dementyev, E.P., Bazekin, G.V., Tokarev, I.N., Lobodina, G.V., Karimov, F.A., Andreeva, A.V., Gizatullin, R.S., Ilyasova, Z.Z., Giniyatullin, M.G. and Bliznetsov, A.V. (2018) The application of physical and biological stimulants in livestock breeding. J. Eng. Appl. Sci., 13(10): 8325-8330.

7. Khabibullin, R.M., Ismagilova, E.R. and Bakirova, A.U. (2018) Morphology of skeletal muscle tissue in mice during exercise and the use of adaptogens. Morphology, 153(3): 288-289.

8. Khabirov, A., Khaziakhmetov, F., Avzalov, R., Tsapalova, G., Andreeva, A. and Gafarova, F. (2020) Influence of the probiotics of lactobifadol on the exchange processes, literal microbiocenosis, productive indicators of goslings. J. Glob. Pharma Technol., 12(1): 54-62.

9. Tagirov, K.K., Gubaidullin, N.M., Fakhretdinov, I.R., Khaziakhmetov, F.S., Avzalov, R.K., Mironova, I.V., Iskhakov, R.S., Zubairova, L.A., Khabirov, A.F. and Gizatova, N.V. (2018) Carcass quality and yield attributes of bull calves fed on fodder concentrate "Zolotoi felutsen". 
J. Eng. Appl. Sci., 13(S8): 6597-6603.

10. Andreeva, A., Nikolaeva, O., Altynbekov, O., Galieva, C. and Ilina, K. (2020) Influence of interferon-based drugs on immunological indices in specific prevention. Vet. World., 13(2): 238-244.

11. Safonov, V. (2020) Assessment of heavy metals in milk produced by black-and-white Holstein cows from Moscow. Curr. Res. Nutr. Food Sci. J., 8(2): 410-415.

12. Mironova, I.V., Kosilov, V.I., Nigmatyanov, A.A., Saifullin, R.R., Senchenko, O.V., Chalirachmanov, E.R. and Chernenkov, E.N. (2018) Nutrient and energy digestibility in cows fed the energy supplement "Felucen". Res. J. Pharm. Biol. Chem. Sci., 9(6): 18-25.

13. Andreeva, A.V., Nikolaeva, O.N., Ismagilova, E.R., Tuktarov, V.R., Fazlaev, R.G., Ivanov, A.I., Altynbekov, O.M., Sultangazin, G.M., Urmanov, I.M. and Khakimova, A.Z. (2018) Effect of probiotic preparations on the intestinal microbiome. J. Eng. Appl. Sci., 13(S8): 6467-6472.

14. Dolzhenkova, G.M., Gataullin, N.G. and Tagirov, H.H. (2017) The consumption patterns and energy utilization of diets with the use of complex supplements BioMarin in feeding cows. Bull. Beef Cattle Breed., 4(100): 182-189.

15. Kolesnik, Y.N., Yurina, N.A. and Danilova, A.A. (2018) Phyto-energy supplement in the diet of highly productive cows. Tauride Bull. Agric. Sci., 3(15): 55-64.

16. Galin, P., Galyaveeva, A., Bataev, H. and Safonov, V. (2020) The role of micronutrients and vitamins in the prevention and remote treatment of heart failure. Rev. Latin. Hipertens., 15(1): 26-32.

17. Lyashuk, R.N., Mikhailova, O.A., Moshkina, S.V. and Samoilov, D.A. (2017) Zootechnical evaluation of cows using feed additives "Atpure" and "Cavelos energy". Bull. Kursk State Agric. Acad., 3(2): 23-28.

18. Vorobyov, V., Vorobyov, D., Polkovnichenko, P. and Safonov, V. (2019) Evaluation of hematological and metabolic parameters in small ruminants with trace elements deficiency under different biogeochemical conditions. Worlds Vet. J., 9(4): 311-316.
19. Smirnova, L.V. and Korshunova, O.V. (2017) Mineral and energy supplement "Minvit R Reactor" in the diets of dairy cows. Chief Anim. Tech., 9(1): 24-30.

20. Nikolaeva, O., Andreeva, A., Altynbekov, O., Mishukovskaya, G. and Ismagilova, E. (2020) Probiotic drugs impact on the innate immunity factors. J. Glob. Pharma Technol., 12(1): 38-45.

21. Khaziakhmetov, F., Khabirov, A., Rebezov, M., Basharov, A., Ziangulov, I. and Okuskhanova, E. (2018) Influence of probiotics "Stimix Zoostim" on the microflora of faeces, hematological indicators and intensitivity of growth of calves of the dairy period. Int. J. Vet. Sci., 7(4): 178-181.

22. Mironova, I., Nigmatyanov, A., Radchenko, E. and Gizatova, N. (2019) Effect of feeding haylage on milk and beef quality indices. In: E3S Web of Conferences. Vol. 135. EDP Sciences, France. p01100.

23. Ventsova, I. and Safonov, V. (2021) The role of oxidative stress during pregnancy on obstetric pathology development in high-yielding dairy cows. Am. J. Anim. Vet. Sci., 16(1): 7-14.

24. Torzhkov, N.I., Maiorova, Z.S. and Blagov, D.A. (2015) Ration 2+ software package for formulating and balancing rations for farm animals. Int. J. Exp. Educ., 5(2): 216-217.

25. Gorlov, I.F., Belyaev,A.I., Slozhenkina, M.I., Mosolova, N.I., Zlobina, E.Y., Randelin, A.V., Bondarkova, E.Y. and Sherstyuk, B.A. (2020) New synbiotic-mineral complex in lactating cows diets to improve their productivity and milk composition. Iran. J. Appl. Anim. Sci., 10(1): 31-43.

26. Kalaeva, E., Kalaev, V., Efimova, K., Chernitskiy, A. and Safonov, V. (2019) Protein metabolic changes and nucleolus organizer regions activity in the lymphocytes of neonatal calves during the development of respiratory diseases. Vet. World, 12(10): 1657-1667.

27. Kakimov, A., Smirnova, I., Zharykbasov, Y., Kakimova, Z., Yessimbekov, Z., Mirasheva, G. and Baybalinova, M. (2017) Specific activity of Cs-137 in milk of Semey region of East Kazakhstan area. Ann. Res. Rev. Biol., 12(5): 1-6. 